\title{
人の動き分布を用いた場の記述に関する研究
}

せんだいメディアテークにおける動き分布図

\section{A STUDY ON THE NOTATION OF MOVEMENT IN SPACE WITH VISUALIZING "THE ACTIVITY VECTOR"}

"The activity vector field" in Sendai mediatheque

\author{
小野田 泰明*, 氏原茂 将**, 浜田勇 樹***, 堀口徹**** \\ Yasuaki ONODA, Shigemasa UJIHARA, Yuki HAMADA \\ and Tohru HORIGUCHI
}

\begin{abstract}
The aim of this paper is to invent a new visual tool to rethink the function of architecture. The research was conducted in Sendai mediatheque to grasp the dynamism of the interrelated activities. The notion of "the activity vector field" enabled us to visualize the relationship between the dynamic aggregation of activities and the space. The findings are as follows. The partial event can affect the overall activities on the floor. Attractors in "the activity vector field" are not connected to the specific activities; but takes different character according to their relative position in the space.
\end{abstract}

Keywords: visualization, notation of the movement, the activity vector field, Sendai mediatheque, function 可視化、場の記述、動き分布、せんだいメディアテーク、機能

1. 序

空間と人間行為の相互関係の探求は建築研究の最も重要なテーマのひ とつであり、現在に至るまで様々な試みがなされてきた。しかしなが ら、アフォーダンス理論やトランザクショナル理論などの両者の不可分 性を指摘する研究領域の発展により、行為と空間を明確に区分し、刺 激 - 反応関係を見ようとする従来の考え方は転機を迎えている。一方、 これと呼応するかのように建築デザイン理論においても変容が起こって いる。建築家が構築すべき対象は単なる物理的空間ではなく、そこに起 こりうる出来事を含んだ動的な概念よして捉えるべきだとする考え方で

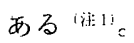

こうした動向は必然的に、建築計画が主要な夕ーゲットとしてきた 「機能」の捉え方を転換させる。決められたサービ入を供給しさえすれ ばよい状況下では、区画された空間それぞれに対応させた機能の組み合 わせ二そが問題であり、平面的な配置設関係をモデル的に解くダイヤグ ラムは、そうした機能操作に有用な手段であった(文10)。しかし、人々 がそれぞれの興味に応じた行動や情報を空間内で発見しつつ選び取って いく環境下では、機能はそこに起こる行為の束の生起確率としてしか捕 らえることが出来なくなってしまう!文!。

ルフェーブルは名著「空間の生産」文31 の中で、建築家が操作する領 域としての「空間の表象」、住まい手が実際に生きている領域としての
「表象の空間」の二項に両者を相対化する能動的知覚としての「空間 の実践」を置くことによって、三元論の限界を乗り越える方策を兒 い出し、それを「空間の生産」という概念で提示した。個々の行為 の層とそれらが存在する空間の層をそれぞれ別個に計測した後に霖 者を関係づけようとする二項対応ではなく、三つの間に流動するい! 為の集積から導き出される層を新たに析出するアプローチを本研究 が採用しているのはそれらに呼応した結果でもある。もちろんさ。 における第三層の提示は、解を示すものではない。しかしながら、建

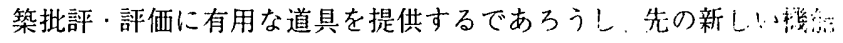
概念に具体的イメージを付与し得るに違いない。

\section{2. 関連研究の展開と本研究の課題}

\section{2-1. 既往研究の到達点}

近接する研究領域として、まず記を挙げておきたい。ひとつは 近年の建築理論の動向である。前述したルフェーブルらによる転換 と同時に建築界でも出来事と構筑環境の境界そのものに建築の姿を 見ようとする流れが生み出されている。千ェミの定式 Architecture=Event $\times$ Space ${ }^{(2) 5)}$ や建築批評家キプニスによる理論化 (文1)などはその代表例のひとつである。最近ではウィットが、せん だいメディアテークのプレート上の場について gravityの比喻を用い
* 東北大学大学院工学研究科都市 - 建築学専攻 助教授 · 博士 (工学)

** フリー 工修

*** 株 ACCESS 工修

**** 東北大学大学院工学研究科都市・建築学専攻 リサーチフェロー・博士 (工学)
Assoc. Prof., Dept. of Architecture and Building Science, Graduate School of Engineering, Tohoku University, Dr. Eng.

Free, M. Eng.

Access Co., Ltd., M. Eng.

Research Fellow, Dept. of Architecture and Building Science, Graduate School of Engineering, Tohoku University, Dr. Eng. 
た説明を試みている(文の。建築家自身による表明としては、先のチュ ミを始めクールハース(文2)、伊東豊雄(文7) などが挙げられる。小嶋 一浩もその著書(文34) の中でそうした考えを直裁的に表明している。 しかし、これらは小嶋を除き実際の行為との対応に関心を置いたもの ではなく、創作表明的な色合いの濃いものであった。

次に挙げられるのが物的環境場の記述を目指したものである。日本 では活動等高線図（アクティビティ・コンター）の作成を中心とした 原、藤井、曲渕らによる一連の研究が代表的である(文9,12,23,24)。これら はフィールドサーベイによって得られた知見を豊かな空間図としてま とめ上げるとともに、行為に影響を与えるしつらえを「アトラク ター」として取り出すなど大きな成果を上げている。

三番目は、群衆流動に関連する一連の研究である。日本では中祐一 郎らの研究(文20)を端緒とするこの流れは、渡辺仁史(文18.19.25)によっ て大きく発展させられ、現在も継続中である。画像処理技術の発達も あり、近年においては鍛佳代子(文13)、小瀬博之(文15.16) らによって乎 法の精緻化を進める研究が展開されるなど広がりを見せている。

\section{2-2. 本研究の位置付け}

第一の流れは、性格上やむを得ない面もあるが、現実空間との関連 に課題を残している。むしろ、理念を検証する具体的アプローチが待 たれていたと言うこともできる。第二の流れは、ユークリッド空間と 人間の生活空間の間に横たわるギャップを埋めるものとして構想され ており、本研究の問題意識に極めて近い。しかし方法論で見ると、物 理環境の性格を物理環境のデー夕を用いて視覚化しようとしており 1: $: 21$ 、行為のパラメータを用いて場を記述しようとする本稿とは異な るアプローチを採用している。そういう点では、第三の流れは本研究 と近い方法論を有する領域である。しかしながら、この研究領域の近 年の興味は、群衆流動そのものの詳細なメカニズムを捉える方向に収 斂しており、初期の渡辺が行ったような人間の分布を関数化して場の 概念を導き出したようなものは例外となっている。従って、行為の状 況を場に返していく方向性には展開の余地が残されていたと言える。

佐々木らが述べるように、行為は常に動きのなかで発生するものた とすると(文17)、従来の使われ方研究の多くのように動きから滞留を 切り出して分析するのではなく、動的状態の中の一チースとして滞留 を捉える方がしっくりくる。本研究で、行為者はまず速度を持った状 態として取り出され、場のデー夕に変換されるのは、そのあたりの断 絶を回避しょうと考えたためでもある。「動き分布」と仮に呼ばれる 行為を時系列で可視化することによって「場」文41 の性格の逆照射が 可能ではないかという我々の試みは、わかり易く言えば、天気図が地
形の物性を捨象し、各地点の爯気の状態を分布として捕らえることで 多くを説明しょうとする態度に近いものである。

\section{3. 分析の対象と方法 \\ 3-1. 分析対象}

動き分布を得るため、2001 年1月に仙台市に開館したせんだいメ ディアテーク（以下、smt）において観測を行った。smtは設計者が述 ベているように(文8) 人が自らの場所と行為とを逐次発見していく環境 となることが構想されている。このように新しい機能の考え方を下敷 きにしていることが、対象として選定した大きな根拠となっている。

観察は 1 階で行ったが (fig.1)、その理由は以下の通りである。1) 施 設全体のエントランスであると同時に都市広場としての位置付けを与 えられ、多様な行為の生起肪想定されている。2）特に中央に広く確保 されているオープンスクエアは様々なイベントが実際に行われ、しつ らえの変化による影響も観察できる。3)上階へと向かう人びとが多く 行き交うなかで、店舗やカフェが設えられ、移動とともに滞留をも観 察することができる。4）天井高が $6 \mathrm{~m}$ と高く、観察のためのカメラの 設置数が少なくて済む上に解析時の精度の確保が期待できる。

\section{3-2. 調查概要}

内部空間の全域をカバーするため 1 階の天井に 6 台のCCDカメラを 設置し(fig.2)、それらから送られてくる映像をデジタルビデオによ二 て録画した。観察を行ったのは2001年10月2 日から20日のうちの9 日間であり。詳細な解析にまわしたのはそのうち 3 日間、オープンス クエアにて一切イベントが行われていない定常状態の10月6日 (Case 1006)、オープンスクエアでコンサートが行われた10月8日 (Case 1008)、街路側の可動壁が開けられオープンスクエア上でワーク ショップが展開された10月4日（Case1004）である。

\section{3-3. 画像処理を用いた動体の抽出方法}

画像処理の手順は、以下の通りであるい211。

1)撮影した映像を、静止画として1秒毎にコンピュータ上に取り込む。 2) 人の映っていない背景画像と時刻 画像との色空間 (RGB) 距離 dcolをピクセル毎に求め、䦭值によりクラスタ（ひとかたまりの部分） を抽出する。

3）クラスタのピクセル座標 $(x, y)$ を求める。この際、3点透視図の原 理を応用し、背詈画像より求めた鉛直方向の消失点 VP3 を使用して。 人の軸線がVP3を通ることからVP3 とクラスタの中心 Mを結んだ筺 線上に人の足元の位置を取る。なおクラス夕位置係数 $\mathrm{kc}$ は、120枚 $\sigma$ : 画像の目視によるデー夕から最小二乗法を用いて決定した（fig.3a；.

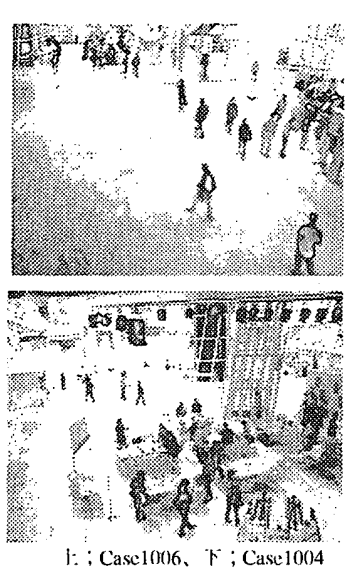

fig.1 smt 1 階での行為

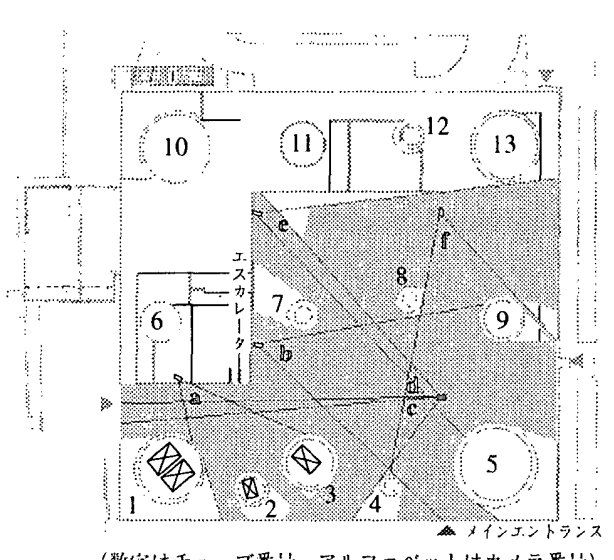

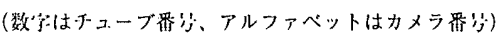
fig.2 smt 1 階平面図と設置カメラ

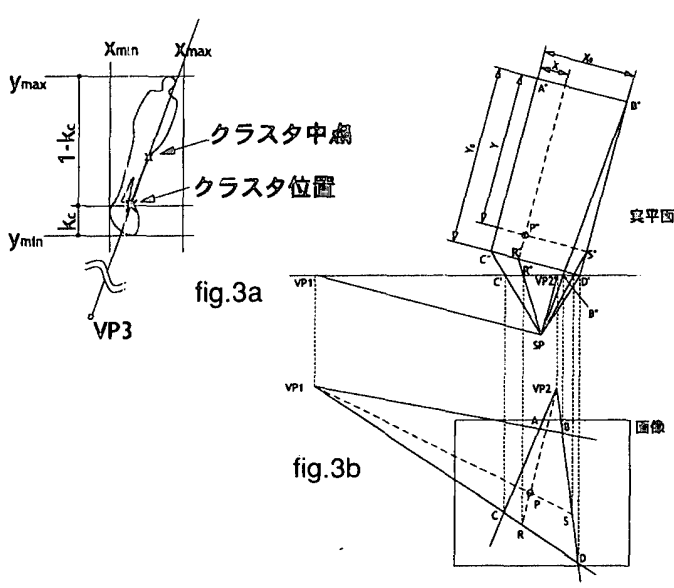

fig.3 座標変換の原理 (ił 31 
4）撮影された画像は実空間の 3 点透視図と考えることができるため、 クラスタのピクセル座標 $(\mathrm{x}, \mathrm{y})$ の逆投影として実空間上の座標 $(\mathrm{X}, \mathrm{Y})$ を算出する。この方法により、実空間において平面的に長方形をなす 4 点 A",B",C",D"の XY 座標と、それぞれの画像への投影点 A,B,C,Dの xy 座標さえわかれば、座標変換することが可能となった（fig.3b)。 5）クラスタに含まれるピクセル数 $\mathrm{s}$ (以下クラスタサイズ) と、視点 SP からの距離 D との関係から選別関数を作成し、人を表すクラスタ (以降、動体と呼ぶ) のみを選別する (位3)。

6）各時刻と次の時刻との間で、動体のマッチングを行う。まず実平 面上の移動距離とクラスタの平均色空間距離による選別を行い、残っ た動体のうち色空間距離とクラスタサイズの変化dが最も小さくなる ように対応付け、速度ベクトルを算出する。なおマッチング係数 $\mathrm{km}$ は、120枚の画像の目視データを用いて決定した。

7）結果をテキストファイルに書き出し、目的に合ったアプリケー ションを用いて位置、速度等の情報を図面上に描画する (ił4)。

\section{4. 記述方法と記述結果}

人の動きを速度 $[\mathrm{mm} / \mathrm{sec}]$ として記述するために、映像を一秒每の静 止画像としてコンピュータに取り込み、速度ベクトルを算出する。続 いて 5 分間分のすべての速度ベクトルを平面図上に重ね合わせて行 く。この際に連続する動きの中から滞留を区分する際の值としては $\lceil 500 \mathrm{~mm} / \mathrm{sec}$ 未満」(泣5) を採用している。

\section{4-1. 動きの状態}

定常状態であるCase1006において、特に人通りが多く变化に富んで いた 14 時 30 分から 35 分までの 5 分間の動きを累積を見たものが fig.4 である。全体的に受付と3番チューブを取り巻くように流動が見られ ており、滞留は入ってきて方向を見定める位置、エレベーターの前な どを中心としながら、微細なものが全体的に分布している。また、比 較的速い動きはオープンスクエアの中央に多いなどの特徽も見られ る。

\section{4-2. 動き分布図}

しかし、これだけでは場の状況を見るには不十分 である。そこで平面図上に1000 mm四方のグリッドを 設定し(泣6)、5 分間に滞留する延へ人数から滞留密度 を求めた（fig.5）。さらに $0.0 \mathrm{~mm} / \mathrm{sec}$ 以外の速度を持 つグリッド内のすべての個体の速度ベクトル $\mathrm{mp}$ スカ ラー量を加算した上でグリッド人数を除し、各グ リンドにおける平均速度量を求めた（fig.6）。各図は それぞれで得た数字を平面図上にコンター図として 表したものであり、本研究でいう動き分布は、前者の 滞留分布と後者の流動分布を基本図として表現しう る場の状態を指すものとする。

\section{5. 動き分布図の変動}

動き分有は常に変動し同じ姿をとることはない。 しかしながらいくつかの変動を見ていくとある特徽 的なパターンが存在することにも気付く。得られた 図を見ながら考察していく。

\section{5-1. 滞留 (fig.5)}

1 番、2 番、3 番のチューブに曲まれたエレベーター ホールに当然のことながら滞留が多く見られるが、
なかでも2番とエスカレーターをつなぐ中央軸上（図中 A）で良く観 察されている。次に目立つのが、受付カウンター前・4番チューブ脇 (図中B）と入った人が方向を見定める位置（図中C）に生じる滞留で ある。しかしこれは、エレベーター近傍のAに比べ変動が多く、周辺 の滞留状況と関連しあっているようにも見える。5番と9番の間にあ るショップが主要動線と接触する箇所（図中D）ならびにフライヤー などが置かれている9番チューブの左端（図中E）においても特徽的 な滞留が起こっている。また、頻繁に流動が起こっているエントラン スとエスカレーターを絮ぐ動線上（図中F）においても軽微な滞留が 見られる。

本棚やエレベーターなどの何らかの行為が期待されているしつらえ 周辺で高密度の滞留が発生している一方、点字ブロック周辺、エスカ レーター脇などでも同様に、帯留密度の高い部分が観察されている。 より詳しく見るために10秒単位で滞留の形成を追ってみると(fig.9) 前者（a）はある程度の時間安定して発生し、行動セッティングのよ うな状況が形成されているが、後者（b）は極めて短い時間の間に発 生・消滅する動きの中の泡のような漁留であり、性格が異なっている ことが分かる。この短い滞留は動きの中でランダムに発生するようだ が、5分間を累計したものに戻ってみると3番チューブの上あたり（図 中 G）に比較的多く発生しているようにも見え、環境要素との関係も 捨象しがたい。

\section{5-2. 動き分布（fig.6）}

滞留よりも大きな速度成分を有する動き分布においてまず特徽的な のは、1番チュープと13番チューブを結ぶ対角線（図中H）すなわち カフェのキャッシャーからエレベーターホールが8番チューブに遮ら れずに直接見通せる直線の下半分にその分布がほほ限定されている点 である。動き分布が比較的濃い部分は、エレベーターホールの奥、エ ントランスから広がりに解放された辺り（図中I）などであり、滞留 が比較的多い部分の近傍に存在する部分である。その一方、8 番 チューブを取り囲む形で動き分布が極めて疎な部分（図中の空白部）
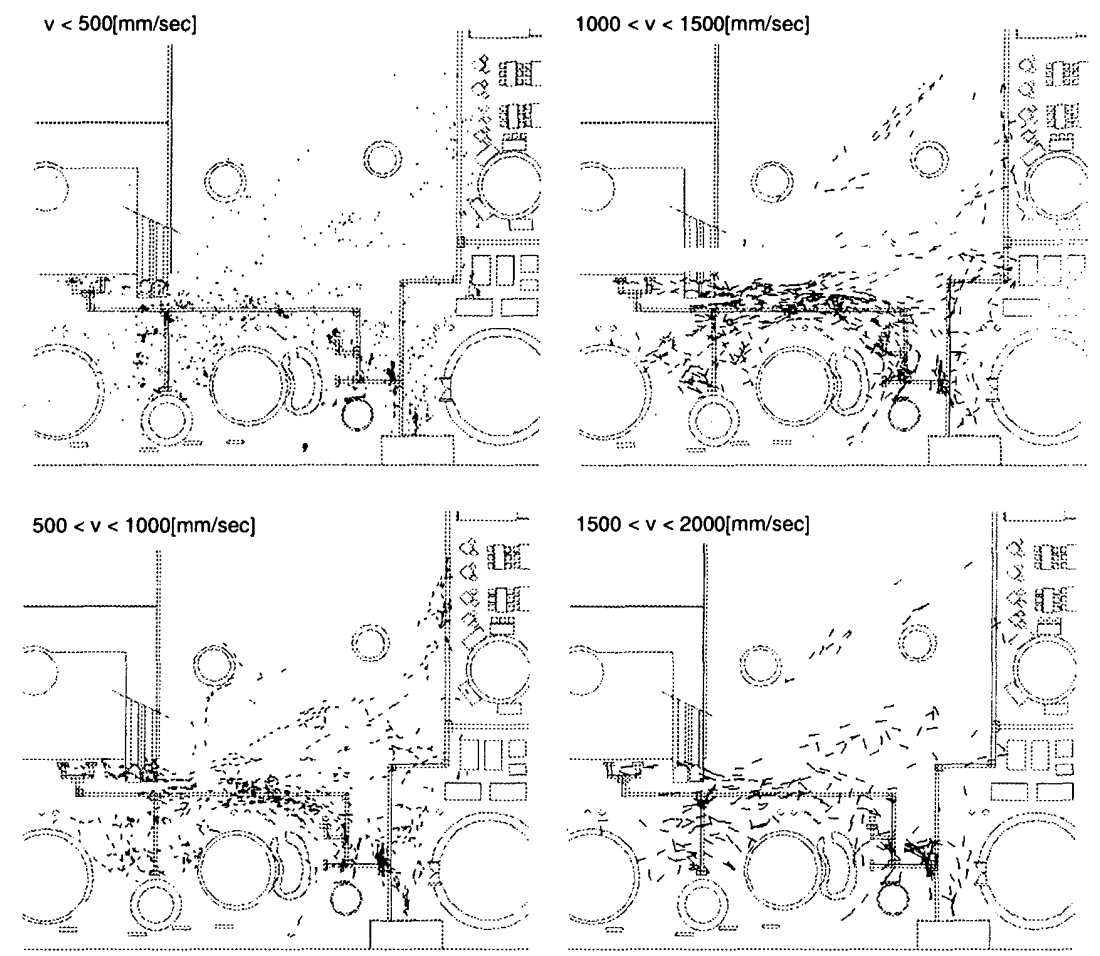

fig.4 Case1006における動きの状態・1430-1435 

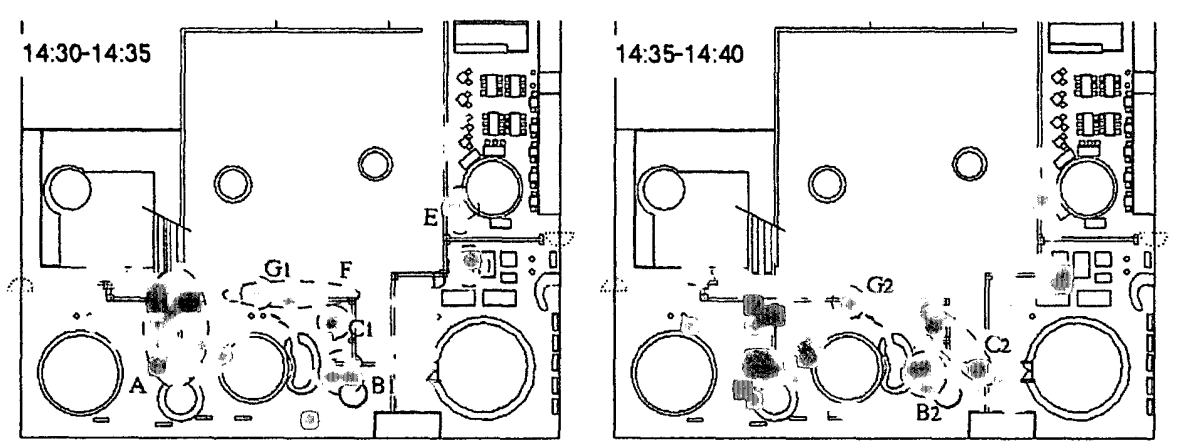

fig.5 滞留分布の変動；Case1006
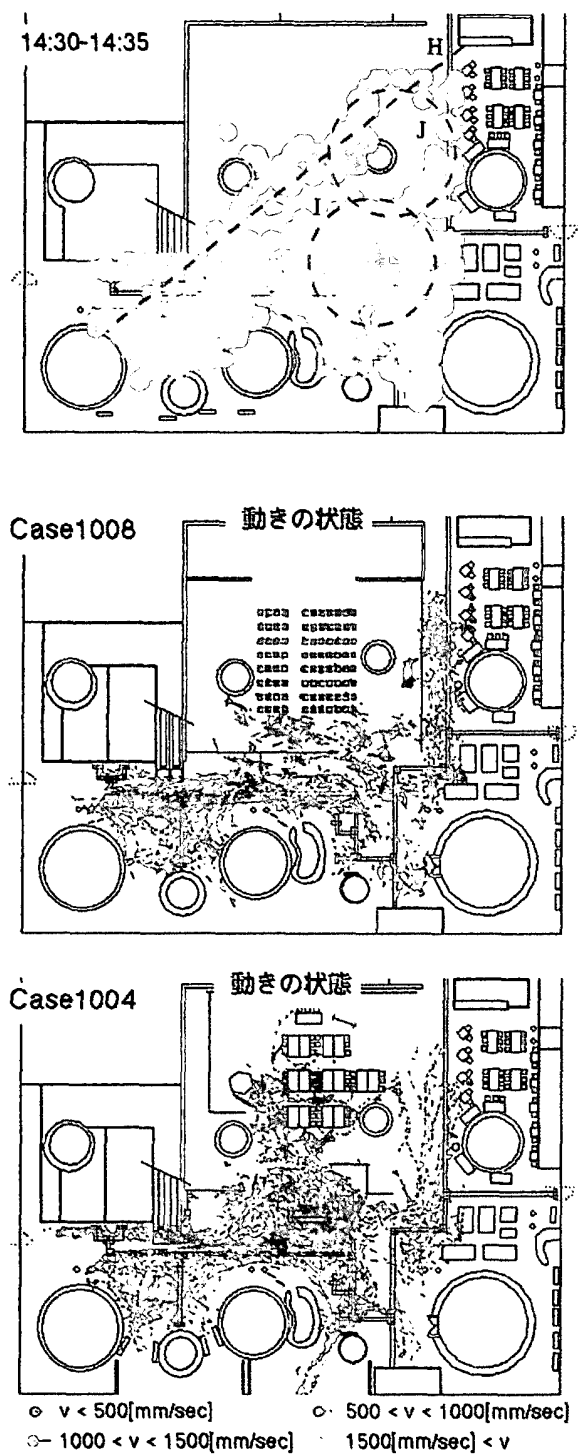

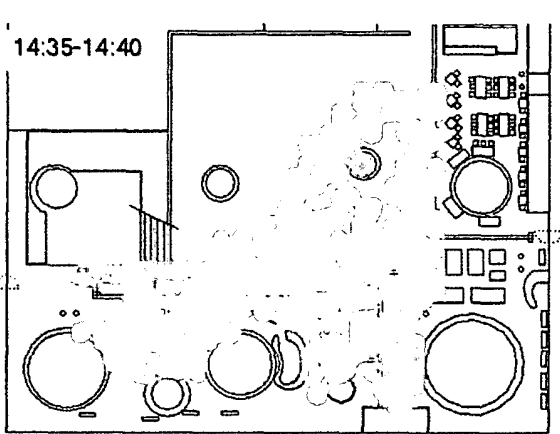

fig.6 動き分布の変動；Case1006
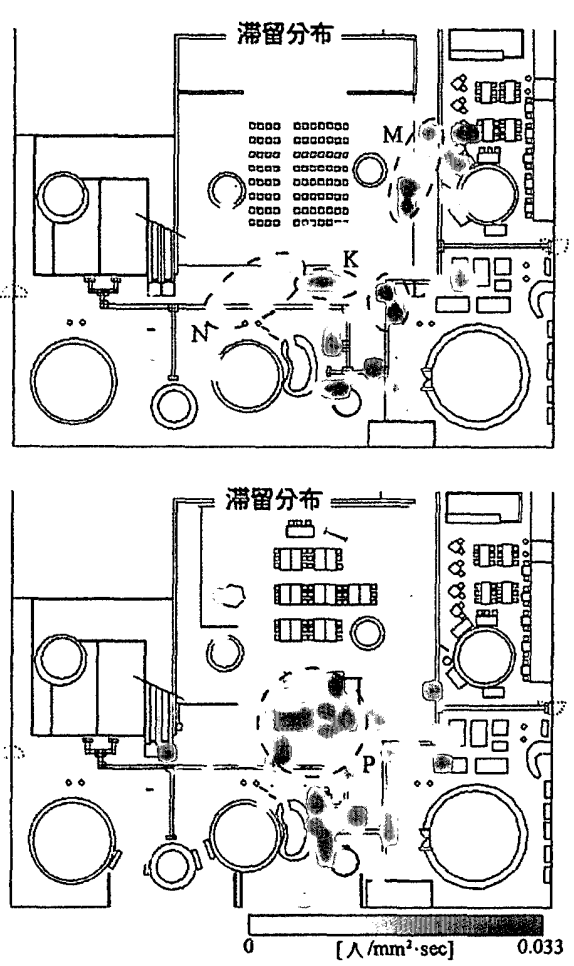
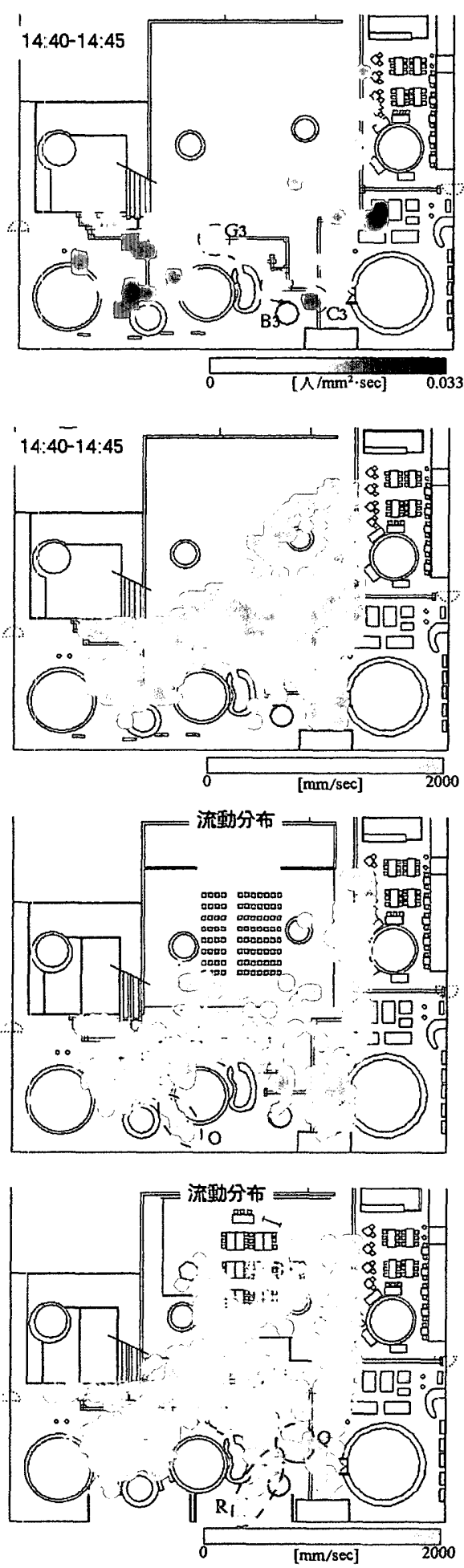

fig.7 しつらえによる分布の变化；動きの状態、滞留分布、流動分布・1430-1435

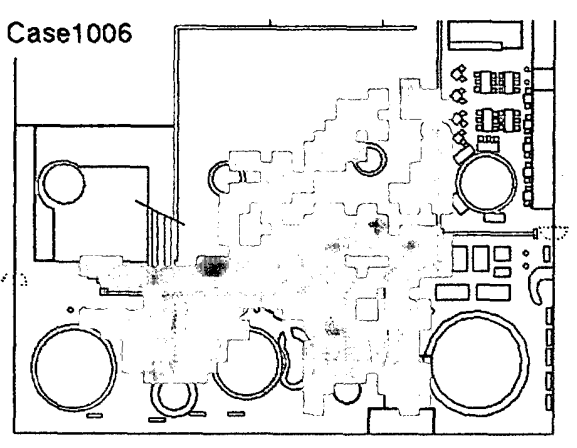

$-66-$

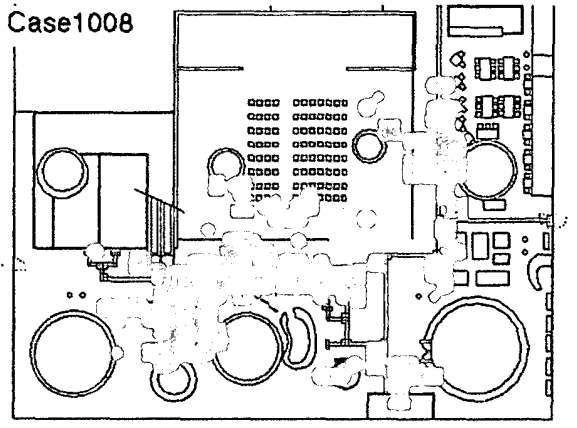

fig.8 移動变化の分布；1430-1435

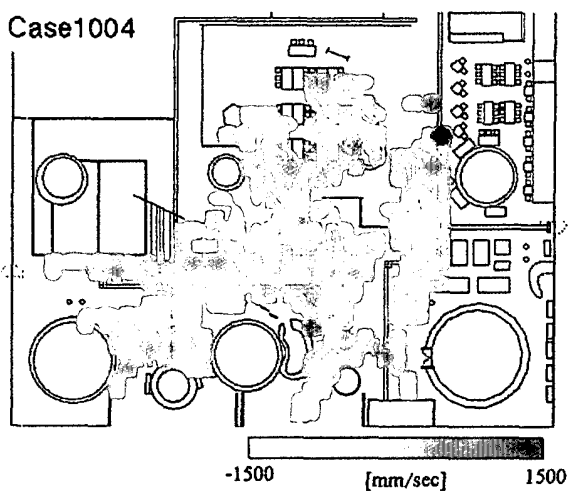


が存在しており (図中J)、時間によって形の変化は見られるもののそ の基本的な形は保持されている。ある安定した性格の場が8番チュー フによって与えられていることが読み取れる。

\section{6. しつらえの変化による動き分布の変化（fig.7）}

前述したようにこの空間は、多様な行為に柔軟に対応することが意 図されている。そこで、しつらえの変わったCase1008、Case1004にお いて先のCase1006と同様な方法を用いて同時間帯の行為を観測した。 6-1.コンサート開催時 (Case1008)

1) 滞留

先の定常状態 (Case1006) に比べるとエレベーターホールにおける 帯留は驚くほど少なくなっている。その一方でオープンスクエアのエ ントランス側に面した端（図中 $\mathrm{K}$ )、同側の点字ブロックの角（図中 $\mathrm{L}$ )、 8 番と 9 番チューフの間（図中 $\mathrm{M}$ )、などに時間の長い滞留が起 こっている。前二者はその位置がイベントを眺めるのに適当であり、 自然と人が集まって出来た滞留と想定され、後者はチューブで挟まれ ることで柔らかい行為セッティングが起こりやすい状態であることが 起因していると推察できる。こうした立ち止まってイベントを見る滞 留は3番チューブの北側にも見られるが (図中N)、このあたりに佇ん でいる観客がエレベーターの到着に合わせてそちらに駆け寄る行為が 観察されていることから、広義のエレベータ一待ちと考えられる。し たがってこの地点における滞留は、エレベーターホールの一時的拡張 ともいえる興味深い動きといえる。

2）動き分布

オープンスクエアの周囲にテープが張られアクセスが制限されてい るために人が移動できる部分が限られ、Case1006に比較すると動きの 平均速度は全体にゆるやかになっている。また、制限によって全体の 動きが南側に押し込められた結果、チューブやチューブ4の裹側 (図 中0)に動きの溢れ出しが起こっている。混雑が起こってもこのよう な溢れ出しによって柔軟に対応しているところは、 smtの特幑のひと つとも言える。

6-2ワークショップ開催時（Case1004）

1) 㴆留

Case1008ではテープで人の移動は制限されていたか、Case1004では そういったしつらえはなく、移動も制限されていない。そうしたこと もあって、大きな滞留が7番、8番チューフの下側（四中P) に生まれ ている。Case1008と同様の理由で、エレベーターまわりの滞留はほと んと見られない。また、受付まわりの滞留は他と同じである。

2）動き分布

大きくオープンスクエア側に動き分布がせり出しており、ワーク ショップ開催の効果が見てとれる。エントランス付近の状況 (図中Q) を帯留分布と比べると、風除室の真上に生まれている滞留の固まりを 避けるような形で動き分布が構成されていることがわかる。また、風 除室の通常出入口よりもその横の4番チューブと受付の間の方に速い 流動が生じるようになっているなど道路側の稼働壁を開放することに
よって分布の変化が生じている(図中 R)。イベントによって滞留す る人が増加したこともあって、全体的に動きの分布は活発となって おり、その展開もフロア全域に渡っている。

6-3. 動き変化分布図

本研究でいう動き変化とは、個々人の単位時間における移動速度 の変化量のことであり、スカラー量として求められる。前述の $1000 \mathrm{~mm}$ 四方のグリッド毎にグリッド内の各個体のスカララー量を加 算し、さらにそれをグリッドに含まれる個体数で除することでグ リッド毎の平均変化量を求めることが出来る。それを動き分布同様、 平面図上にコンター図として再整理したものが fig.8である。全体的 に減速が多く見られるのは、速度の速い状態で施設内に入り、次第 に減速するためと考えられる。特に 8 番チューブと 9 番チューブの 間に細長く展開する速度变化は、減速が連続的につらなっており、 奥にいくにしたがって徐々に平均速度がゆっくりとなっている。

動きの変化する領域は空間全体に散在しているか、そのなかでも 本棚やエレベーターなどの何らかの行為が期待されているものの周 辺に変化の大きい領域が観察できる。滞留 (fig.5, fig.7) と合わせな がらその分布性状を見ると、加速域と減速域とが隣り合うよう分布 しており、帯留行為に付随する減速域（滞留に至る）加速域（滞留 から離れる)であると推察される。

また、Case1006におけるオープンスクエア中央付近やCase1008に おけるオープンスクエアのエントランス側に面した部分でも減速域 が発生しているか、これは他の人との交錯や混雑により生じている ものと考えられる。こうした減速は滞留へと続くものというよりも、 むしろ移動のなかに埋め込まれた変化だと考えられ、既往の研究成 果'(文18,19) とも符合する。

\section{7. まとめ}

観測を行ったのは交通が定常的に起こっているエントランス階で あったため、風除室とエスカレーター・エレベーターをつなぐ主要 な流れを中心に動き分布は形成されていた。しかし、視覚化によっ て実際の流れの複雑な疎密関係も示すことが出来ている。以下、得 られた結果について概説する。

1)帯留には行動セッティングとして比較的安定し存続するものと行 為の中で消えたりするゆるやかなものが存在している。前者はエレ ベーターや本棚などの具体的要素とセットになることが多いか、後 者については動きの中で発生しており、関係は読み取りにくい。し かしよく見るとチュープ近傍や点字ブロックの端で起こることが 多く、柔らかな親和力の存在を類推させる結果となっている。

2) 8 番チューブ近傍に動き分布・滞留両者の見られない場が安定し て発生しているように1)の滞留の起こり易い場所とは反対に起こり 難い場、すなわち斥力が働いているとでも言える場の存在を確認し た。動き分布の可視化により、通常は確認が困難なこのような場に ついてもあぶり出すことが出来た。

3)イベントによってフロア上の動き分布状態が大きく恋動すること

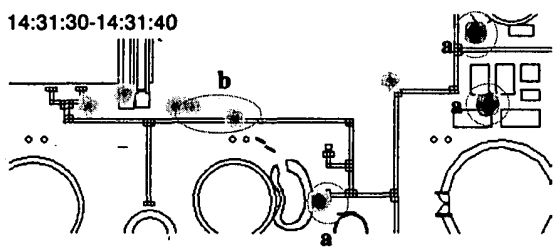

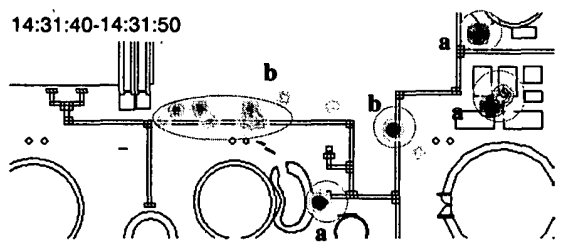

fig.910 秒間隔で見た滞留分布の変化 : case 1020

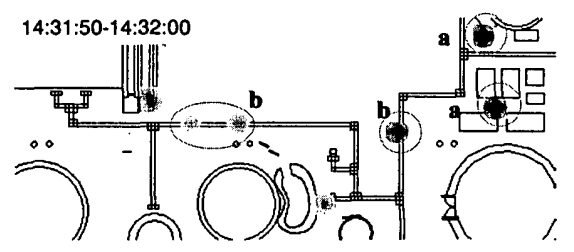


が分かった。そうした変化は、オープンスクエアとその近傍といった しつらえによって直接影響を受けるところに留まらず、フロアの端の 方にも影響が及んでいる（具体的にはエレベーターホールの拡張、 チューブから南側への溢れ出しなど)。これれが起こりうる背景とし て、全体的な見通しと移動の自由が確保されていることはもちろん、 微妙な環境の差異がチューブなどによってっくられているといった、 このフロア空間がもつ性質が関連しているとも考えられる。

4)8番チューブが移動に関する場に挟まれながらも絶えず移動が生じ ていない場所となっている一方で、その隣の9番チューブには動きが まとわりつくなど流れの中の位置付けによってチューブの性格は変化 する。1）や2）に見るように、チューブは動き分布の特巽点となる 性向を有しているのだが、それは特定の動きと一対一で結びついてい るのではなく、全体の流れにおける位置付けによってその働きかけの 内容は大きく変化する。また、8番チューブ周りで顕在化したように その性向は弱いセッティング時にあらわになるようにも見える。

5）今回の動き分布の観測を通じて描かれた図は動き分布「場」が チューブ間で生起していること、実際の有様はより複雑であることを 除けば、エフェメラルという形容を含め設計者が初期に想定していた 「場 (領域)」という概念と比較的高い親和性が認められる (fig.10)。 もちろん拙速な評価はあり得ないが、抽象的な設計意図が現実化して いる一端を捉えられたようにも思う。

動き分布という概念を用いることによって、通常は捉えることが困 難であった刻々と流動 する個別行為の群を空 間と関連づけて記述す ることが可能となった。 今後は、新しい機能 を標榜する同系の施設 をフィールドとしてさ らにデータを増やすと ともにその生成メカニ スムや活用方法につい ても探る予定である。

謝辞；奥川恵美子前館長を 始めとするせんだいメディ アテークには、研究の意㴽 をご理解顶いたたで、smt コンソーシアムの一鿓とし て多人なサポートを頂い た。また、菅野賽教授、坂
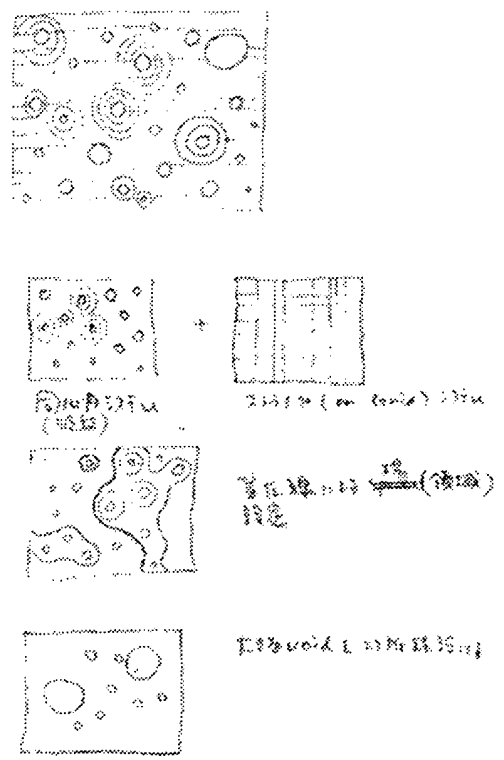

fig.10伊東によるスケッチ(文)

口太洋氏には様々な助言を頂き、プログラム開発段階では小林規久男君の官献 を受けた。さらに設計者である伊束豊雄氏、事務所スタッフの占林豊彦氏らの 方々にも貴重な助言とサポートを頂いた。もちろんその他多くの方々の協为も 頂いている。ここに記して謝辞に代えさせていただきたい。

\section{注媇}

1)空間への囲い込みにより本米そこで生起する行為の多梯性や連䋽性を限定しな い開か机た建築の可能性を描き出したものとして、Rem Koolhaasの「ジュシー 网䓙館コンペ案」(1993) や例東豊雄の「せんだいメディアテークコンベ策」 (1995) などが挙げられる。

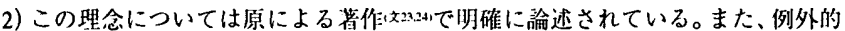
ではあるが、この研究ダループ大河内らは、都市内出行萑分们を等涪線汹で表 記することで、場を可視化しようとしている。こうしたアプローチは本破究の 立場に近く興味深い:邓。

3）椅子に座っている人や机や本棚によって作が部分的に暚れている人は、手法.上
そのクラスタを動体として析出することが難しいため本研究では除外した。カ フェ内や音楽祭の客席上で滞留や動きの記载がないのはそのためである。

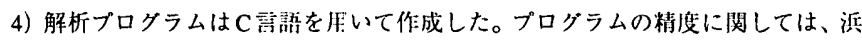
田が一秒海の㖕 120 枚の画像から目視および画像処理による人の位置・速度の 抽出粘果を比較した結果、332 データ中 275 の抽出に成功した。平均誤养は 195.78mmであり、400mmを超える謡差はほとんど兒ら机ないことから良好な精 度で人の抽出とその位置座潔を測定することができるものと判断した れン。

5) 人問工学分野の既往調査では歩行時における成人男性の平均步幅を $700 \mathrm{~mm}$ と しており ス26、そこから $500 \mathrm{~mm}$ の範囲に収まる動きであ机ば移動を旨とした動 きではないと判断できる。また、混雑による歩行負荷が加わらない状態での步 行速度が約 $1200 \mathrm{~mm} / \mathrm{sec}$ 丈26 であることから、1000 $\mathrm{mm} / \mathrm{sec}$ を閥值としてそれ以 下をゆっくり歩く状態、そ机以上を通常歩行と見なして差し支えないと考えた。 さらに $1500 \mathrm{~mm} / \mathrm{sec}$ 以上というのはかなりの速さと考えられるが、解析時に $2500 \mathrm{~mm} / \mathrm{sec}$ を限として速度ベクトルを描いたところ、2000 $\mathrm{mm} / \mathrm{sec}$ を越えるこ とははとんどないものの実绦に $1500-2000 \mathrm{~mm} / \mathrm{sec}$ あたりでかなりの人が步行し ている状況を確認できた。よって、速度べクトルの描写にはfig.4のような速度 区分を用いることとした。な书単位として、 $\mathrm{cm} / \mathrm{sec} て ゙ は な く ~ \mathrm{~mm} / \mathrm{sec}$ 用いてい るのは、本研究が行為記述でなく、空間記述に眼差しを向けているためである。

6) グリッドコンバージェンスは次の乎順で行なった。 $\mathrm{smat} 1$ 階の約 $50 \mathrm{~m} \times 50 \mathrm{~m}$ とい う大きさから表現上 $20 \times 20$ 以上のグリッド数が必要と判断し、解像度の下限を まず設定した。その条件下での最大幅は $2000 \mathrm{~mm}$ であるが、成人の平均歩行速 度が $2000 \mathrm{~mm} / \mathrm{sec}$ 以下のためこの場合、同一步行者がーグリッドに何度も含まれ て、動き分布の動的状態が猆現し難くなることがわかった。そこで $1000 \mathrm{~mm}$ と $500 \mathrm{~mm}$ で試行を行なったが、500mmでは歩行速度に対して目が練かすぎ分布を 上手く描写できなかった。それらを踏まえ、最終的には $1000 \mathrm{~mm}$ を採用した。

\section{参考文献}

1) Kipnis, J. : Towards a New Architecture, Folding in Architecture, AD, 1993

2) Koolhaas, R. : $S, M, L, X L$, the Monacelli Press, 1995

3）Lefebvre, H.：空間の生産 - 社侌学の思想 5, 斎藤日出治訳, 青木杳原, 2000

4）Lewin, K.：社会科学における場の理論, 猪俣佐登留訳, 誠信書原, 1956

5) Tschumi, B. : Architecture and Disjunction, the MIT Press, 1996

6) Witte, T. : CASE:TOYO ITO - SENDAI MEDIATHEQUE, PRESTEL, 2002

7）伊束豊雄：近代を超える「もうひとつの空間」, 新建築, 新建築杜, 2001.3

8) 伊東豊雄建築設計事務所編著: 建築:非線型の出来事 smtからユーロへ, 彰国非: 2002

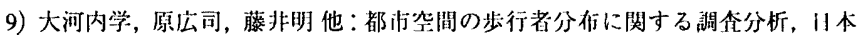
建築学会大会学術講演梗概集 F-1, pp.693-694, 1996

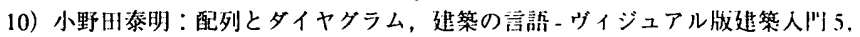
彰国社, 2001.3

11）小野田泰明：コミュニケーション叮能態としての建築へ, 新建築 3 月号, 新建 築杜, 2001.3

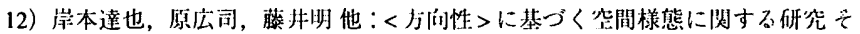
の1, 日本建筑学会大会学術講演梗概集 E-1，pp.905-906, 1995

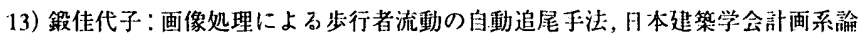
文集, 493, pp.195-200,1997.3

14）小嶋一浩：アクティビティを設計せよ！，彰国社，2000

15）小瀨博之, 紀谷文樹: 水景施設に扔ける人の行動の解析に対する画像処理の適 用，日本建築学会㖕画系詥文集，481，pp.75-81，1996.3

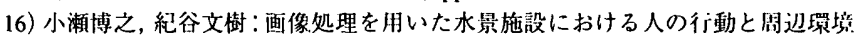
の解析，日本建築学会計国系論文集，509,pp.65-70, 1998.7

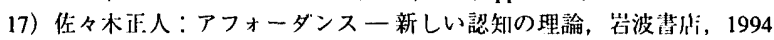

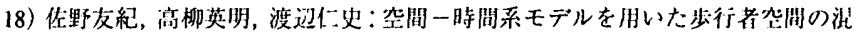

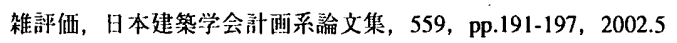

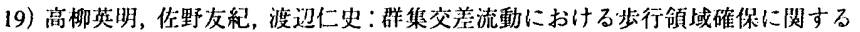
砄究一步行領域モデルを用いた解析一, 日本建築学会計画系論文集, 549 , pp.185-191, 2001.11

20）中㭪一郎：交差流動の構造一鉄道駅における交錯流動に関する研究（1）一， 日本建築学会碖文報告集, $258, p p .93-102,1977.8$

21）浜田再樹，小野田泰明他：画像処理を用いた建築空間内における行動の記述法 に関する研究，日本建築学会大会学術請演梗概集 A-2, pp.401-402，2000作

22）浜田勇樹，小野旧泰明他：教科教室型中学校の運用に関するケーススタディそ の2-其用空閏における生徒の滞留・通過行動, 日本建築学会大会学術講演梗概 集 E-1，pp. 253-254， 1998

23）原広间：空間<機能から様相へ>, 岩波背店，1987

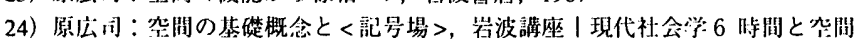

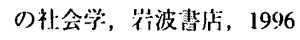

25）渡辺仁史，中村良:，浜目管他：人間一空間系の研究その6 突間における 人间の分㑈のパターン解析, 日本建築学会計画系論文集, 221, pp.25-30, 1973.7

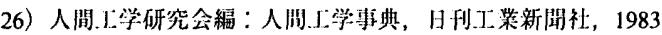

（2003年 4 月 10 日原稿受理，2003年 6 月19日採用決定） 